\title{
Trajectories of Internationalization: Knowledge and National Business Styles in the Making of Two Dutch Publishing Multinationals, 1950-1990
}

\section{DICK VAN LENTE \\ FERRY DE GOEY}

The internationalization of business is the subject of an extensive theoretical literature as well as a growing number of historical studies. Historians have paid relatively little attention to the development of multinationals in the service sector, and studies about international publishing are especially scarce. This article discusses the early internationalization of two Dutch publishing firms, Kluwer (now Wolters Kluwer) and Elsevier (now Reed Elsevier) and confronts these case histories with the evolutionary theory of internationalization. The Dutch cases underline the important role of experience, knowledge and learning as well as of the national context in which companies develop. They also show that these factors allow for very different trajectories of internationalization within the same branch of business and the same country.

Since the 1970s, research on multinational corporations has expanded enormously, reflecting the growing internationalization of business. ${ }^{1}$

(c) The Authors 2007. Published by Oxford University Press on behalf of the Business History Conference. All rights reserved. For permissions, please e-mail: journals.permissions@oxfordjournals.org.

doi:10.1093/es/khm078

Advance Access publication December 4, 2007

DICK VAN LENTE Faculty of History and Arts, Erasmus University Rotterdam. E-mail: vanlente@fhk.eur.nl, degoey@fhk.eur.nl.

1. For the current state of affairs in business history, see Amatori and Jones, eds., Business History around the world; Chandler, Amatori, \& Hikino, eds., Big business and the Wealth of Nations. On the historiography about Big Business 
Our knowledge of how and why companies cross borders to conquer foreign markets has increased, though there are still gaps in our understanding of the process. ${ }^{2}$ The literature on multinationals is primarily concerned with foreign direct investment (FDI) and portfolio investment (PFI) of (very) large manufacturing companies. Where service sector firms are discussed, it appears they simply followed the manufacturing firms, setting up foreign branch offices to aid these companies (e.g., financing, transport, and insurance). This is justified to some extent, since a large part of the service sector is indeed closely related to industry. ${ }^{3}$ From the 1980s, for example, large industrial companies started to outsource their service needs, stimulating the growth of the service sector. However, companies in the service sector also possess specific characteristics, which influence their internationalization strategy. For this reason, and because services now account for almost half the total world FDI, the service sector deserves closer attention. ${ }^{4}$

Recent studies on the internationalization of services have covered trading companies, shipping, insurance companies, accountants, consultants, banks, and airlines. ${ }^{5}$ Relatively little attention has been paid so far to international publishing, even though very large international multimedia concerns have emerged in the 1980 s. $^{6}$ We

(American research only): Klein, 'Coming Full Circle,' Enterprise and Society 2 (2001): 425-60.

2. Jones, 'Business Enterprise and Global Worlds,' Enterprise and Society 3 (2002): 581-605.

3. Numerous case studies are included in: Bonin, ed., Transnational Companies; Jones, ed., Transnational Corporations; Jones and Schröter, eds., The Rise of Multinationals in Continental Europe. Interest in the service sector is growing. See Buckley, Pass, and Prescott, 'The Internationalization of service firms', in The Internationalization of the Firm, ed., Buckley and Ghauri, 149-65.

4. The distinction between services and products is not always evident. See Dunning, 'Multinational Enterprises and the Growth of Services,' The Service Industries Journal 9:1 (1989): 6-9. According to Geoffrey Jones, using FDI as a proxy for measuring multinationals is misleading because services are not always very capital intensive and companies also use local resources for their investments. See Jones, 'Business Enterprise', 588.

5. Jones, The Evolution of International Business; Jones, Multinationals and global capitalism; Jones, 'Business Enterprise', Sluyterman, 'Internationalisation of Dutch accounting firms', 581-605.

6. Book history is an expanding field. Although it covers the production and distribution of books, it has not paid much attention to international publishing. See the yearbook Book History and Altbach and Hoshino, eds., International book publishing. A query produced no scholarly articles on the publishing industry in Enterprise and Society or Business History. Business History Review showed just one related article since 1991: Neiva, "Chain building: The consolidation of the American newspaper industry, 1953-1980," Spring 1996 Older contributions to other history journals include: Springhall, "Disseminating Impure Literature; 
consider publishing is part of the service sector because its core business consists in serving customers by finding, selecting, editing, and distributing content. ${ }^{7}$ In the first section of this article we will demonstrate that specific characteristics of publishing have led to specific internationalization strategies. Section 2 will briefly outline those theories on internationalization which seem to be most relevant to the service sector, including publishing. The next two Sections present case studies of two Dutch multinational publishing firms, which will be used to test these internationalization theories. Section 3 presents a detailed analysis of the decision-making process at an early stage of internationalization of the Dutch publisher, Kluwer (at present, Wolters Kluwer). This case study is based on primary sources from the company archive, especially the records of meetings of the managing and supervising directors, published reports, and some articles and books written by scholars and journalists. Apart from some general remarks, we will not go deeply into the development of Kluwer's foreign subsidiaries after their acquisition, since this would require substantial archival research for all these firms. In Section 4, we will briefly compare the Kluwer case to the internationalization of another Dutch publisher, Elsevier (today, Reed Elsevier), using published sources (e.g., annual reports, books). The purpose of this comparison is to demonstrate that different internationalization strategies existed within the publishing business and within the Dutch national context. In Section 5, we will evaluate the theoretical insights we have used in our analysis, and suggest some refinements that may guide further research into the history of international publishing and the service sector generally.

Our argument can be summarized as follows:

(1) Acquisitions were the preferred method of expansion of publishing firms, both at the home market and abroad. This can be attributed to certain characteristics of the industry, especially the importance of knowledge.

(2) The case history of Kluwer not only reflects the characteristics of the publishing industry, but also points to factors characteristic of the Dutch context.

(3) The importance of the national origins of Kluwer should, however, not be overemphasized, because Elsevier followed a dissimilar trajectory of internationalization. To explain

Rubin, Self, Culture, and Self-Culture in Modern America” Byrnes, "The French Publishing Industry and Its Crisis in the 1890s."

7. Jagersma, Multinationalisatie van Nederlandse dienstenondernemingen, 66. 
Table 1 Scientific and Medical Publishers by Market Share (2001)

\begin{tabular}{lccccc}
\hline & \multicolumn{2}{c}{ Science } & & \multicolumn{2}{c}{ Medical } \\
\cline { 2 - 3 } \cline { 5 - 6 } Company & Share (\%) & Rank & & Share (\%) & Rank \\
\hline Reed Elsevier & 23.3 & 1 & & 32.2 & 1 \\
Wolters Kluwer & 3.7 & 6 & & 22.3 & 2 \\
Thomson & 5.7 & 2 & & 20.2 & 3 \\
McGraw-Hill & 3.2 & 7 & & 2.9 & 5 \\
John Wiley \& Sons & 5.4 & 4 & & 1.2 & 6 \\
\hline
\end{tabular}

Source: Morgan Stanley Equity Research Europe, Scientific Publishing: Knowledge is Power (London, September 30, 2002).

these differences we must look at their company histories and the different market niches they targeted.

Both Dutch firms have been very successful in the publishing industry. By the end of the twentieth century they ranked among the largest publishers in the world (see table 1).

The Book Business and Internationalization

Because publishing firms differ in many respects from other branches of industry, their growth paths also have specific characteristics. ${ }^{8}$ We have defined publishing as a service business, even though until the nineteen-seventies, many Dutch publishers had extensive printing facilities. Since the production of print underwent so many technological changes during this period (photo setting, offset printing, text and image processing computers ${ }^{9}$ ), and since from the late nineteensixties some publishers started to experiment with new publishing formats, for example, computer databases, one might expect considerations concerning technology and production to play an important role in decisions about international expansion. The management records we have used show that this was not the case. At Kluwer, printing was organized in a separate division, which was entirely subservient to the publishing divisions. During the fifties, it produced print for the mother firm at prices $10-15 \%$ below the price outsiders had to pay (even below cost price, if necessary), and when a manager

8. Excellent discussion of these characteristics in Coser's, Books. The culture and commerce of publishing.

9. Van Lente, 'Copy, composition, printing (printing presses, printing ink) and correction.' 
of the printing division accepted more orders to keep the presses running, resulting in delays in the printing of Kluwer's own books, he was severely reprimanded. ${ }^{10}$ When during the sixties the managers started to discuss the expansion of Kluwer, they focused entirely upon product-market combinations. Production facilities were hardly discussed at all and neither were electronic databases. What mattered was what types of content to produce for whom. While during the period of diversification some printing firms were taken over and investments were made in new machinery, after 1970 these facilities were increasingly considered too costly and not very lucrative and they were increasingly being sold off, as we will see. ${ }^{11}$ We therefore, feel justified in considering publishing as mainly a service business. As to computer related technologies, they seem to have become more prominent only at the end of the period studied. ${ }^{12}$ The most important sunk capital of the publishers here studied, and most other publishers as well, were therefore in the backlist or catalogue (the book titles the company owns the copyright of), their knowledge of particular market niches, and the goodwill of their customers.

The importance of knowledge derived largely from the fact that the print market was highly segmented in terms of language, content (e.g., education, entertainment, news, science), and carriers (journals, magazines, newspapers, hardcover books, paperbacks, e-books). An intimate knowledge of the market and the ability to single out new trends were therefore of paramount importance. This filtering and selection process was usually taken care of by a firm's editors, who maintained and developed a network of authors and other potential providers of content.

The takeover of a publisher, therefore, did not usually require the acquisition of expensive production facilities but was, in most cases, limited to the publisher's catalogue and editorial staff. The purchase price thus depended on the market value of the backlist and the expertise of the editors of the publishing house. Acquiring a

10. Wolters Kluwer archives, Notulen Commissarissenvergadering 6 January 1951.

11. See, for example, intensive discussions about acquisitions in Wolters Kluwer archives, collection Resius box 16, nr 162, meeting of managing and supervisory directors 16 December 1968; and ibidem: Ontwerp prospectus explaining the first emission of shares. Here, acquisition of publishing firms was given as an explanation, not the need to invest in production facilities. Ibidem Vergaderingen Raad van Commissarissen en directie, 11 November 1975.

12. See about the role of ICT in international acquisitions by Dutch publishers: Van Kranenburg, Cloodt, and Hagedoorn, 'An exploratory study of recent trends in the diversification of Dutch publishing companies.' 
publisher with a well established market position was usually much safer, faster, and cheaper than trying to open up a completely new market niche, which required investments in building up a network of contacts with authors and finding a market for the new product.

Because of these characteristics, mergers and takeovers have been a normal feature in the book business since at least the late nineteenth century. Merger waves in publishing have corresponded well to those in other parts of the business world. ${ }^{13}$ Except for the USA and Great Britain, which had been markets for each other because of their shared language, international activity in publishing was fairly limited before 1970. Mergers, therefore, took place mostly within national borders. The USA had its huge home market, and European countries had their colonies to focus upon. ${ }^{14}$ The variety of languages and cultural differences in Europe restricted internationalization. One important exception to this rule was scientific publishing, where the English language became dominant after World War II, and which profited from the explosive growth of science and technology during the Cold War years. Elsevier was one of the pioneers in this market, as we will see.

From the late 1960s on, large European publishers began to feel constrained within their national markets, and started to buy up firms abroad. ${ }^{15}$ The merger wave of the sixties and seventies resulted in highly diversified companies. ${ }^{16}$ The economic downturn in the eighties, following the second oil crisis, reversed this trend. Large firms such as Kluwer and Elsevier decided to reinforce the most profitable parts of their businesses and to sell the less profitable ones. This resulted in a focus upon scientific, professional and educational publishing. Elsevier managers explained the logic of these choices by means of the following diagram. (See figure 1)

The three uppermost levels were characterized as "need to know"information, as against the "nice to know"-information at the bottom of the pyramid. At the very top were scientific books and journals. They were mainly produced in very limited print runs for university libraries. Because of their "need to know" character, the influence of the business cycle was small and profit margins were very high: between 30 and 40 percent. ${ }^{17}$ At the next level in the pyramid

13. Coser, Books, 22-29; Graham, 'Multinational publishing,' in International book publishing. 242-49.

14. For international activities of Dutch publishers in the nineteenth and twentieth centuries, see Dongelmans, 'Foreign trade,' in Bibliopolis. History of the printed book in the Netherlands; Van der Weel, 'Foreign trade,' in Ibid., 242-43.

15. Graham, 'Multinational publishing', 244-45.

16. De Jong, Fusies en overnames.

17. Vermeulen and De Wit, Onder uitgevers, 246-49. 


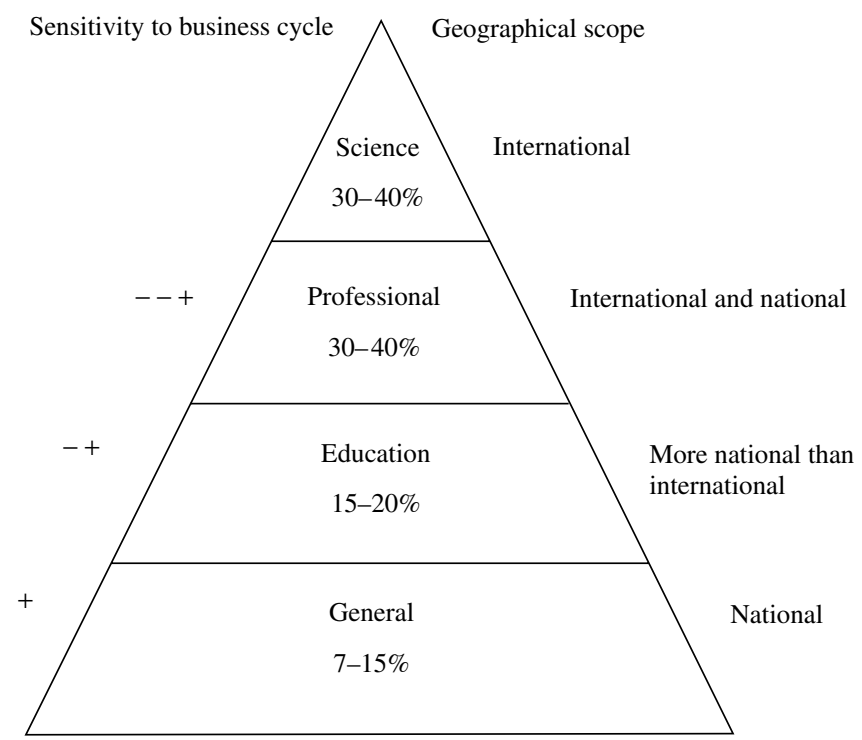

Source: P.K. Jagersma, Multinationalisatie, 70.

Figure 1 Publishing triangle.

were professional and trade journals. Here, print runs were larger and dependence on the business cycle was somewhat greater. This sector was not as international as the academic one, but almost as profitable. Print runs were again larger on the next level: educational publications. Due to differences in educational systems between western countries, these publications were much more national, with the exception of English and especially American college text books that were popular all over the world. Profit margins in this sector were estimated at $15-20 \%$. At the lowest level, with the largest print runs and profit margins of $7-15 \%$, an almost exclusively national orientation, a high dependence on income from advertising, and therefore, a great sensitivity to fluctuations in the trade cycle, were publications for the general public, such as novels, books about gardening and cooking, newspapers, and magazines. These hardly lent themselves to internationalization. A Kluwer executive nicely illustrated this in 1980, when he pointed out to his superiors that it was impossible to create a German version of a Dutch fashion magazine, because the Germans lagged two years behind the Dutch in fashion. ${ }^{18}$ At the very bottom of the pyramid were bookshops

18. Wolters Kluwer Archives, RVC, nr. 98 (meeting supervisory directors 18 juni 1980). 
and printing facilities. These tied down much capital and were only marginally profitable. ${ }^{19}$

\section{Theory: the Internationalization of Companies}

In his study on the FDI of companies in several small European countries, Harm Schröter counted well over 800 different motives leading firms to internationalize. ${ }^{20}$ Looking for patterns in these motives, scholars have developed general theories on international trade, and more particularly, FDI. ${ }^{21}$ The one that is most applied is John Dunning's eclectic paradigm, the so-called OLI-model, developed in the $1970 s^{22}$ According to Dunning, firms engage in FDI if they possess advantages based on ownership, location, or internalization.

In 1989, Dunning applied the eclectic paradigm to the service sector, but his exercise remained largely theoretical, and he did not discuss publishing. ${ }^{23}$ At the end of his article, Dunning summarized his findings in a table listing several variables considered important in the internationalization of some service sector industries. The OLI-model provides a handy framework for organizing factors encouraging internationalization of companies, including services. ${ }^{24}$ A major problem with this model, however, is the large number of variables that are potentially relevant ("the shopping list critique") and the equally unlimited number of possible combinations of variables that can be headed under either ownership, location, or internalization advantages. According to Dunning the "configuration of these advantages will vary according to industry, country or region, and firm specific characteristics", ${ }^{25}$ Furthermore, the model does not include a time dimension, important in historical research: some variables become

19. Vermeulen and De Wit, Onder uitgevers, 45; cf. Jagersma, Multinationalisatie, 70. Where Luykx found this idea, or whether he dreamed it up himself is not known, but its basic ideas can already be found in Van den Brink's essay in Elsevier, Annual Report 1976, 408. It is also mentioned in Schiffrin, The Business of Books, 117. See also the interesting interview with Vinken in Van Wermeskerken, De jaren 90, 227-53.

20. Schröter, Aufstieg der kleinen, 165-90.

21. Jones, The Evolution of International Business, 3-21.

22. Dunning, 'The Determinants of International Production'. See also his 'professional autobiography': Dunning, 'Perspectives on International Business Research'.

23. Dunning, 'Multinational Enterprises,' 5-40.

24. Cantwell and Narula, 'The Eclectic Paradigm in the Global Economy'.

25. Dunning, "Multinational Enterprises," 10. 
more important over time, while others loose their importance. Dunning addressed most of these critiques by extending and reconfiguring the original eclectic paradigm. For instance, the concept of the investment development path (or cycle) (IDP) introduced a dynamic element in the eclectic paradigm. This theory tries to explain how and why the configuration of the OLI advantages of countries and companies investing in these countries changes over time, affecting inward and outward investments. ${ }^{26}$ Dunning and others also applied the eclectic paradigm to investigate nonequity alliances, PFIs, external networks, alliance capitalism, and patterns of trade. ${ }^{27}$ He further acknowledges the increasing interaction between ownership and location advantages, particularly in the case of innovation, R\&D and technological accumulation. ${ }^{28}$

In recent years, a new theory on internationalization has emerged, which emphasizes knowledge and learning: the "Evolutionary Theory of the Multinational Corporation". ${ }^{29}$ This theory can be taken to both specify Dunning's paradigm and adding a historical dimension to it, in that it emphasizes the importance of knowledge as an ownership advantage, and the acquisition of knowledge as a historical process. Insofar as knowledge is incorporated from outside the company, we may take this as a form of internalization. Evolutionary theory suggests that firms will first export their products using agents, then establish a small market presence (e.g., sales offices), followed by production using imported parts, and finally production based on locally manufactured parts. ${ }^{30}$ It is not necessary for companies to

26. Dunning and Narula, Foreign Direct Investment and Governments.

27. Dunning, "The Eclectic (OLI) Paradigm of International Production” and Idem, "The eclectic paradigm of international production: a personal perspective". See also the collection of essays: Gray, Extending the Eclectic Paradigm in International Business.

28. Cantwell, "A survey of theories of international production”.

29. Kogut, "The Evolutionary Theory of the Multinational Corporation”; Idem, "Country Capabilities and the Permeability of Borders"; Kogut and Zander, "Knowledge of the Firm and the Evolutionary Theory of the Multinational Corporation"; Idem, "Knowledge, Market Failure and the Multinational Enterprise: A Reply”. See also, Verbeke, "The evolutionary view of the MNE and the future of internalization theory".

30. This sequence is known as the Uppsala internationalization model. The main features of the model include a sequential or stage model of internationalization, cumulative learning processes, and path dependency. The model was first presented by Johanson and Vahlne, "The Internationalization Process of the Firm". The validity of the model has been tested on numerous case studies in different countries. According to Björkman and Forsgren, there is considerable support for the model, although not undisputed. See Björkman and Forsgren, "Nordic International Business Research. A review of its development". See also Eriksson, Majkgård, and Sharma, "Path Dependence and Knowledge 
pass through all these stages. A firm may bypass intermediate stages and some are born global. ${ }^{31}$ Some companies will stop at the second stage, while others may, in the end, return to a previous stage. ${ }^{32}$ After the closure of its assembly line, the Dutch subsidiary of the Ford Motor Company became a sales office, as it had been before the Second World War. ${ }^{33}$

This model was developed with mainly manufacturing firms in mind, and therefore is not necessarily useful for the analysis of services. Research on services points towards the existence of several other forms of internationalization, including transfer of people (e.g., consultants, accountants), transfer of information over the wire (e.g., reports sent over the Internet), joint ventures, franchising, licensing, and strategic alliances. ${ }^{34}$

The version of evolutionary theory developed by Bruce Kogut and others stresses incremental learning processes of companies while they internationalize their business. Skills and experiences gained in the home market are used for entering and competing in foreign markets. Companies will thus favor markets that most resemble their home market (have a low degree of "psychic distance"), because this allows them to utilize their own knowledge. Since this knowledge is acquired at home, internationalization will also reflect certain national preferences and cultural factors. Following this line of reasoning, companies will retain their national characteristics even while becoming more international.

Because companies tend to expand into markets resembling their home market, we may expect the learning process to develop relatively slowly at first, then accelerate, as companies acquire more experience in the countries they have expanded into. The evolutionary theory distinguishes several types of learning. For our purpose, two basic types are important. 'Routinized' learning means that companies develop their existing knowledge and capabilities by applying them abroad. Experience in foreign markets will gradually broaden the knowledge base for additional investments abroad. Companies may then try to conquer different markets and sell products not related to their initial knowledge base. This type of learning is called

Development", and several case studies in Buckley and Ghauri, eds., The Internationalization of the Firm.

31. Knight and Cavusgil, "Innovation, organizational capabilities, and the born-global firm".

32. Dicken, Global Shift, 138-39.

33. De Goey, "Ford in the Netherlands, 1903-2003".

34. Problems concerning a definition of services are discussed in Roberts, Multinational Business Service Firms, 8-21. 
"exploratory" or nonroutinized because it changes existing company routines and introduces alternatives. ${ }^{35}$

Regarding the choice of entry mode, the evolutionary theory points towards the nature of the knowledge firms develop in their home market. Existing knowledge is usually already codified (e.g., articulated in manuals, blue-prints), which favors joint ventures and licensing. New knowledge is often not codified and more tacit. If this type of knowledge prevails in a firm, acquisitions are preferred because certain business practices have to be imposed upon the new firm, rather than sharing data or facilities. Tacit and noncodified knowledge is often costly and more time consuming to export. This kind of knowledge is usually a major source of competitive advantage that firms might want to exploit when they internationalize. ${ }^{36}$

Acquisitions, however, are relatively risky and costly when compared to joint ventures and licensing, while the potential for learning new skills and knowledge is lower. Integrating existing firms in a company requires more managerial effort and may ultimately fail because of unanticipated cultural differences. This risk is lowered when acquisitions are made in countries with smaller "psychic distance". ${ }^{37}$ The type of governance may further limit risks: subsidiaries that operate rather independently from the parent company do not require much managerial intervention. The choice of entry mode will ultimately depend upon industry characteristics (e.g., level of innovation, capital requirements) and company experience, which is connected with a company's history and the national business culture in which it has developed. For instance, companies from highly risk-adverse countries will prefer licensing and joint ventures. ${ }^{38}$ In order to understand trajectories of internationalization, we therefore need to take into account the national contexts in which companies acquired their initial knowledge and skills. The economic history of the Netherlands from the late nineteenth century helps to explain why this small country produced no less than three multinational publishing companies (VNU is the third, besides Kluwer and Elsevier). It also sheds some light upon the styles of management that were developed here.

Because of their small home market and often limited natural resources, small countries usually need to be more internationally

35. Hagedoorn and Narula, Evolutionary understanding of corporate foreign investment behaviour, 3-6.

36. Kogut and Zander, "Knowledge of the Firm," 637.

37. Kogut and Singh, "The Effect of National Culture".

38. Ibid. 
oriented than larger ones. But while most of them specialize in a small number of export products and services (such as dairy products in the case of Denmark, or shipping and fish in the case of Norway), Dutch foreign trade and investment in the twentieth century was much more diversified. ${ }^{39}$ This can be explained by its position between the industrial giants of the late nineteenth century, Britain and Germany, leading to mass production of foodstuffs for export and the flourishing of shipping and related services (e.g., banking, insurance). It also put a premium on language skills. In addition to being important as a trading partner, Germany was also a leading country in science, and many Dutch natural scientists had contacts with German colleagues. This turned out to be a critical advantage in scientific publishing.

An extremely rich colony, Dutch East India (later: Indonesia), provided raw materials (e.g., oil, coffee, and sugar), stimulating industrial growth and transportation. Already before 1920, the Netherlands, therefore, had a number of internationally active companies, such as Royal Dutch/Shell and Van den Berg \& Jurgens (Margarine Union; later Unilever). During the nineteentwenties, Philips (electronics) and Akzo (chemicals) also grew into multinational companies, and after the Second World War, DSM (coal, chemicals) and Hoogovens (iron and steel; now Corus, after a merger with British Steel in 1999) became important. One result of this wide-spread international activity was that in the Netherlands there were many entrepreneurs and managers who were familiar and confident with foreign languages, customs and institutions-skills that were critical for international business. ${ }^{40}$

Geert Hofstede and Peter Lawrence have described national styles of management. In 1967-1969, and again in 1971-1973, Geert Hofstede interviewed about 88,000 IBM employees in 66 countries (as we will see, this was a crucial period in the internationalization of both Kluwer and Elsevier). His survey revealed national differences on four indexes: individualism, femininity, power, and risk-taking

39. For a general discussion, see Wilkins's “Dutch Multinational Enterprise in the United States".

40. "[In 1985] 39 out of the 50 biggest enterprises in the Netherlands (Dutch or foreign-owned) were multinationals. Almost half of them had a higher turnover abroad than at home (...) A recent survey of eight Dutch multinationals shows that only some 25 percent of their turnover is produced in the Netherlands and that, on average, 37 percent of their personnel are employed here." De Goey, "Dutch overseas investments in the very long run (c. 1600-1990)”, 32-60. See also, Narula and Van Hoesel, "Outward investment from the Netherlands"; Van Zanden, Een klein land in de 20e eeuw, 21-25, 48-58 [transl. J.L. The Economic History of the Netherlands 1914-1995, London, 1998]; van Iterson and Olie, "European business systems: the Dutch case," 98-116. 
(time horizon was added later). According to Hofstede, the Dutch are rather individualistic, highly feminine and prefer low levels of power distance. They are somewhat risk-averse, while their time horizon is moderately long. ${ }^{41}$ They also believe material rewards are less important than a good quality of life. Like other European managers they are used to dealing with diversity, are people-oriented and accustomed to consult several stakeholders, not just the shareholders. Reaching consensus, although time consuming, is considered very important by the Dutch. ${ }^{42}$ Aggressive methods of internationalization (e.g., hostile takeovers) are, therefore, not to be expected in Dutch companies. Internationalization will tend to proceed in a piecemeal fashion.

Peter Lawrence, in his book published in 1991, used secondary sources and interviews to investigate Dutch managerial practices. According to Lawrence, a "[...] cardinal feature of Dutch business is internationalism". ${ }^{43}$ This international outlook is stimulated by the Dutch preference to downplay nationality, to assimilate and adapt to foreign cultures and by language skills. Lawrence believes that these cultural traits are rooted in the heterogeneity of Dutch society in terms of religion, which has expressed itself in the educational system, political parties, labor unions, and the media (a phenomenon known as "pillarization"). This has fostered, he thinks, a certain respect for different cultures. ${ }^{44}$ These cultural traits are also evident in prevalent managerial styles. Dutch management, according to Lawrence, prefers informal structures, honesty, long-term relations, stability, and reliability. "The serious American focus on the minutiae of marketing and strategy, performance monitoring and accountability, sometimes seems a little excessive to the Dutch". ${ }^{45}$

The theoretical literature, therefore, leads us to expect some specific features in the internationalization of publishing firms, as well as some characteristics of the Dutch version of this process. Given the highly variegated nature of the print market and the many differences between countries, knowledge is a decisive factor in international expansion. Whether acquisition or joint venture is the favored entry mode depends to a large extent on the type of knowledge (codified or implicit) involved. The Dutch economic and cultural context favored internationalism and fostered a style of management that was characterized by avoiding great risks, low levels of power distance,

41. Hofstede, Cultures and organizations; Idem Culture's Consequences.

42. Bloom, Calori and De Woot, Euro management, 17-25.

43. Lawrence, Management, 2.

44. These observations were made in 1991; they are perhaps no longer valid.

45. Lawrence, Management, 120. 
decision making based upon consensus and reckoning with broad interests, not just those of shareholders. Let us now confront these hypotheses with the history of Kluwer.

\section{Kluwer, 1885-1989: from Family Firm to Multinational}

The Kluwer firm was started in 1885 by Aebele Everts Kluwer (1861-1933), a school teacher who had turned to publishing. ${ }^{46}$ His first publications were connected with teaching: schoolbooks, children's books, and periodicals for teachers in primary and secondary education. During these early years he also published a reference work on the poor laws, aimed at town officials. This turned out to be the beginning of a rapidly expanding field. In 1898 Kluwer launched a periodical that grew into one of the success stories of the firm: a weekly advertising journal called Vraag en aanbod ("demand and supply"), which was sent free of charge (from 1902 for DFL 1, for a year) to industrial firms, municipal governments, architects, railway stations and hotels, and which yielded rich profits from advertising. Its articles about new machines and products became a major resource for engineers and businessmen for keeping up with the latest developments. Because it soon reached a large audience, it offered an ideal advertising medium for a series of books and periodicals on technologies such as that of automobiles, electricity, and telephones.

Another very profitable venture started with the acquisition of a textbook series in fiscal law called De Vakstudie (literally “professional studies"), intended both for the instruction of aspiring officials and as a compendium. During the nineteen-twenties the series became available in loose-leaf form, which made it easy for subscribers to insert supplements. This was the beginning of a long series of loose-leaf publications on all kinds of legislation, aimed at administrators, officials, and lawyers. Gradually, Kluwer achieved a practical monopoly in this field in the Netherlands. The loose-leaf system remained dominant until the arrival of computer based reference works during the 1980s. Kluwer also acquired a local newspaper (1913) and during the 1920s established a modern printing unit, mainly for his own publications. The company was still small,

46. For the history of Kluwer until 1960, see van Lente, “Kluwer, family, experts and managers: 1920-1960”, Conference paper. The Kluwer archives are at Wolters Kluwer's main office, Apollolaan in Amsterdam. We are greatful to Wolters Kluwer for allowing us to consult the Kluwer files. 
employing, in 1909, some eight persons at the office in Deventer, as well as some salesmen and the writers and editors who worked for Kluwer as a sideline to their own jobs.

By the nineteen-twenties Kluwer had, therefore, created a firm consisting of a printing establishment, a newspaper, a small educational list, and very successful lists of professional information for practitioners in law, taxation, industry, and technology. The continuity with the present-day multinational Wolters Kluwer, which according to its annual report for 2006 aspires to be "the professional's first choice”, is striking. It shows Kluwer's understanding (or perhaps intuition) of the growth of legislation and technology in modern society, and the expanding demand for professional information this would create.

Kluwer had four of his six children well prepared for succeeding him: the eldest son studied business, the second law, the third printing, while his eldest daughter prepared for becoming secretary in the firm. The brothers and their sister started to work for Kluwer between 1914 and 1921. In 1929 Kluwer handed the management of the business over to his sons. The company was split into two limited liability companies: a printing company, NV Salland, led by the youngest son, and a publishing company, NV Kluwer, led by the eldest. The second son was in a difficult position between his two brothers. He eventually started his own list of esoteric literature, at first within the Kluwer company, later as an independent firm. Stocks remained within the family. The elder Kluwer served as supervisory director until his death in 1933, when two of his sons-in-law became supervisory directors (joined later on by the Kluwer's second son and his third son-in-law). After the Second World War, the Kluwer firm entered a phase of spectacular growth, which put severe stress upon the family based form of management and financing (see table 2).

Table 2 Growth of the Kluwer Firm, 1945-1954

\begin{tabular}{|c|c|c|c|c|}
\hline & 1945 & 1948 & 1951 & 1954 \\
\hline NV Kluwer: employees & n.a. & 53 & 64 & 80 \\
\hline NV Kluwer: turnover (× 1,000 guilders) & 376 & 1,677 & 2,725 & 3,278 \\
\hline NV Kluwer: profit before tax $(\times 1,000 \text { guilders })^{\mathrm{a}}$ & 56 & 260 & 530 & 672 \\
\hline NV Salland: employees & n.a. & 102 & 111 & 140 \\
\hline NV Salland: turnover $(\times 1,000$ guilders $)$ & 242 & 706 & 1,010 & 1,317 \\
\hline NV Salland: profit before tax $(\times 1,000 \text { guilders })^{\mathrm{a}}$ & 26 & 143 & 112 & 44 \\
\hline
\end{tabular}

Sources: Wolters Kluwer archives, collection Resius, box 5 nr. 81, report of accountants Klynveld, Kraayenhof \& Co to the Nederlandsche Participatie Maatschappij NV on the NV Uitgeversmaatschappij Ae. E. Kluwer te Deventer, 30 juni 1955; and Wolters Kluwer archives, collection Resius, box 5 nr. 82, report of accountants Klynveld, Kraayenhof \& Co to the Nederlandsche Participatie Maatschappij NV on the NV drukkerij Salland te Deventer, 28 june 1955

a In the reports cited for this table this is called "netto resultaat". 
With the growth of the economy and the coming of the welfare state, the demand for Kluwer's main publications boomed. The printing business (Salland) doubled the number of its linotypes and both companies invested heavily in office machinery. Clearly, the companies had much difficulty in adjusting to the new size of operations. At their offices, a clear division of tasks was lacking, and the administration was constantly lagging behind. A consultancy firm hired in 1955 noted, besides these problems, that the firm had no sales and marketing section to speak of. This was understandable given the almost automatic growth of the markets Kluwer was working for, but it could become a problem in the future. ${ }^{47}$ The Kluwers then decided to attract a professional manager from outside the family to help them solve these problems and to guarantee the continuity of the firm after their retirement. In 1957, J. M. Gorter became managing director of Kluwer. His appointment was connected with the resolution of the second big problem: the need for capital.

The financial policy of Kluwer had always been to pay for investments from its own savings (internal financing), at the cost of bonuses and dividends to the family, and in an attempt to keep ownership in family hands. There were two problems with his policy. In the first place, the investments needed to keep the companies going exceeded the means of the family. And second, while the value of the two companies had more than tripled between 1945 and 1955, this wealth was represented in a limited number of shares, owned by only six shareholders. Kluwer shares were therefore so expensive as to practically preclude the possibility of sale (in case a shareholder died, for example), and heirs would have to pay excessive death duties. For both reasons it made good sense to create more shares, allow family members to sell part of them and to invite outside investors to participate in the firm.

In 1956 therefore, a share of DFL 500,000 was taken by the Nederlandse Participatie Maatschappij (NPM), or Dutch Investment Company, a bank created by the government after the War in order to promote industrial growth. The six supervisory directors representing the families of the elder Kluwer's six children were joined by investment banker M. Sanders, who represented the NPM on the board of directors. As the minutes of the meetings between the managing directors and the supervisory directors show, Sanders was very influential from the beginning. He had the managers

47. Wolters Kluwer archives, Resius collection, box 5, $\mathrm{nr} 83$, report by Van Heus of the consultancy firm Meertens. 
draw up a business plan in order to make publishing decisions more transparent. Since the NPM required frequent financial reports, Kluwer's administration was made more efficient. Free services and unspecified payments to the Kluwer family from the company's funds, were cancelled. The yearly meeting of the family stockholders became less important. Strategic decisions were now taken at the meetings of the board of directors with the board of supervisors. During the nineteen-sixties, the board of supervisors came to include two representatives of the company's bank, Algemene Bank Nederland (ABN, today ABN AMRO). These men contributed their financial acumen and connections and they played a pivotal role in the decision to bring Kluwer stock to the market in $1967 .{ }^{48}$

Sanders was also influential in selecting the new managing director J. M. Gorter. Gorter had no previous experience in publishing. He had been an employee at plantations in the Dutch East Indies, and a manager in a factory of woolen products in Leiden. It was his ambition to make Kluwer the largest publishing business in the Netherlands. Though he did not achieve this (in 1974, Kluwer was the second largest Dutch publisher ${ }^{49}$ ), the company certainly changed a great deal under his leadership. Gorter started a sales department which conducted market research and the company transformed itself into a medium-sized managerial firm. ${ }^{50}$

Kluwer's expansion during the 1960s was part of a broad merger wave in Dutch business, which is usually attributed to three causes. The first one is increasing national and international competition after the "sellers market" of the nineteen-fifties had faded away. European economic integration and the appearance of American subsidiaries are often mentioned in the literature. Diversification was one way to spread risks. Especially relevant for the publishing industry was the spectacular increase in wages after the government abandoned its policy of centrally directed wages in 1964. Because publishing is a very labor-intensive activity, firms tried to improve their efficiency by increasing the scale of their operations. Finally, many Dutch managers

48. Wolters Kluwer archives, RvC (minutes of the meetings of the managing directors and the supervisory directors), file A 55, 19 January 1967, 31/67, 37/67; also Wolters Kluwer archives, Resius collection, box 16, nr 162, 10 December 68; 29 March 1969: preparation for introduction of Kluwer shares at the Amsterdam stock exchange.

49. Wolters Kluwer archives, report by McKinsey, "Kluwer N.V.: securing profitable growth. Introduction" (1975), p. 6.

50. The Kluwer brothers retired from management in 1958 and 1966, joining the supervisory board. 
were deeply impressed by American management theories extolling the large multidivisional firm. ${ }^{51}$

The firms Kluwer took over during the 1960s were mostly Dutch companies with lists closely resembling its own. Noorduyn, for example, acquired in 1961, published schoolbooks and fiscal works. Veen, a literary publisher, was taken over in 1965 mainly for its technical and government publications, while Tjeenk Willink was the main remaining rival on the juridical market; it was taken over in 1968. By that time, Kluwer had reached the limits of expansion within Dutch borders in the field of law and to a lesser extent in technical and educational publishing. Internationalization was, however, not considered a serious option at this time, since it would require "an altogether different kind of organization”, as one director said in 1968. ${ }^{52}$ There were still sufficient possibilities in the domestic market, provided Kluwer was willing to diversify into general publishing. This would involve "leaving our more or less sheltered position and entering the battle area, where relatively large companies like VNU are active." 53 If Kluwer decided not to enter this market, it would itself be taken over by either VNU or one of the other large Dutch firms, such as Elsevier and Wolters, it was believed. ${ }^{54}$

These considerations led to the takeover, in 1969, of two family firms: Zomer \& Keuning and Oosthoek. With no top managers claiming positions (these firms were led by gentlemen who were close to retirement), it was relatively easy for Kluwer to incorporate these firms into the company. However, these acquisitions could no longer be financed by the firm's own resources or by bank loans. After becoming a limited company and accepting outside financial advisers and professional managers, Kluwer now took the next step. On the advice of the ABN, and with the blessing of the family, Kluwer shares were introduced at the Amsterdam stock exchange in 1967.

As to coordinating the activities of so many different publishing activities, Kluwer, like most other Dutch companies that internationalized, developed a decentralized structure. ${ }^{55}$ The annual report on 1975 clearly stated: "Consequently, at Kluwer operational and

51. Sluyterman, Kerende kansen, 165-66, 203-13, 230 [transl. Dutch Enterprise in the Twentieth Century, London, 2005].

52. Wolters Kluwer archives, collection Resius, box 16, $\mathrm{nr}$ 163, Raad van Comissarissen, 10 December 68.

53. Wolters Kluwer archives, collection Resius, box 16, $\mathrm{nr}$ 162, Raad van Commissarissen, 16 December 1969.

54. idem.

55. About this general tendency Sluyterman, Kerende kansen, 229. 
entrepreneurial responsibilities are primarily delegated to the managements of operating companies - each functioning as independently as possible." 56 Each operating company was to develop its own publishing strategy, while administration and distribution would be taken care of by central units. ${ }^{57}$ The idea was that in this way the firm would make optimal use of the expertise of managers in their specific market niches and stimulate their creativity and entrepreneurial drive.

By this time, Kluwer had some activities on foreign markets. A subsidiary in Cologne, resulting from the takeover of the Dutch publisher, Stam, in 1967, was only moderately successful. In Belgium, Kluwer had a distribution center for Dutch language books and magazines, as well as schoolbooks. Unprofitable establishments in France and Switzerland were closed, and in 1978, Eska, in Bielefeld (Germany), a subsidiary of Zomer \& Keuning (acquired in 1969 as we saw), was sold.

When Gorter retired in 1969, Kluwer employed 2,883 people (as compared to 341 when he joined the firm in 1957) and company profits increased from DFL 1,674,000 in 1964 to DFL 3,125,000 in 1968. Kluwer had successfully transformed itself from a family firm into a managerial firm.

Gorter was succeeded by H. Klopper, formerly manager of a tinplate factory in Deventer. His primary mission was to consolidate the firm, following the years of rapid expansion. ${ }^{58}$ This he did, but he also presided over the first more-or-less systematic effort at international expansion. This took basically two forms. The first strategy was taking over several Dutch scientific publishers: Martinus Nijhoff in 1970, Junk in 1972, Stenfert Kroese in 1973 and Reidel in 1976. Although these were all Dutch companies, they did strengthen Kluwer's international orientation. Martinus Nijhoff and Junk published mainly English language work for the international market. ${ }^{59}$ Reidel also worked for the international market and had a subsidiary establishment in Boston. ${ }^{60}$

56. Kluwer Jaarverslag (Annual report) 1975, 22; compare 1969, 18; 1970, 7; 1973, 8, 1990 (Wolters Kluwer), 21-23.

57. Kluwer, Annual reports, 1968-1970.

58. This is how Klopper himself characterized his work at the end of his term. See Wolters Kluwer archives, Raad van Commissarissen, 11 November 75.

59. Wolters Kluwer archives, archief Wolters Samsom, WSG 460, bijlage over internationalisatie van Elsevier, Kluwer en VNU, Kluwer, 2.

60. Wolters Kluwer archives, archief Wolters Samsom, WSG 460, bijlage over internationalisatie van Elsevier, Kluwer en VNU, Kluwer, 2. In 1974, 25 million, on a total 65 million worth of exports, was owing to Nijhoff. 
The second strategy was taking over and integrating, from 1974, two small German law publishers, Kommentator and Metzner, in Frankfurt. Both published in loose-leaf form, making them even more similar to Kluwer. The owners were reaching retirement age and eager to sell their businesses. Because these firms, although small, had a recognized position among German lawyers, Kluwer regarded them as a beach-head from which the German market could be penetrated. ${ }^{61}$ Both firms were reasonably profitable after the takeover.

Other options for internationalization were also considered at the beginning of the seventies, but they were rejected. A "greenfield investment" would require creating a market for the new firm, which was very difficult in a country one was not familiar with. A joint venture was another option. The one Kluwer started with Harrap in Great Britain in 1971, trying to sell loose-leaf professional publications, was however consistently losing money. ${ }^{62}$ In general, Kluwer's board of directors rejected international joint ventures because it made it more difficult to impose Kluwer's business practices.

Klopper and his colleagues also had to deal with the internal organization of the company, after the incorporation of so many new firms and with the prospect of expansion abroad. Although the company was structured in functional groups (printing, bookshops, educational publishing, and so on) the "span of control" of the general management was extending. In 1974, the consultancy firm McKinsey was hired to provide advice on its future structure and strategy. ${ }^{63}$ McKinsey's detailed analysis did not lead to fundamental changes, and confirmed Kluwer's preference for decentralized management, allowing the operating companies significant scope for initiative, and retaining brand names of firms that had been taken over. ${ }^{64}$ When the

61. Wolters Kluwer Archives, Raad van Commissarissen, box 3.006, meeting of supervisory directors, 14 november 1973, nr. 51, idem, 4 April 1974. Kluwer's banker, ABN, had suggested several foreign firms for acquisition, which the managers found too large (idem, 4 April 1974). More information about the takeover of Kommentator and Metzner in Wolters kluwer Archives, collection Resius, box 8, nrs. 97, 105, box 9 nr. 114,

62. Wolters Kluwer Archives, Zevenbergen collection, microfilm BZ 473.Stenfert Kroese to Zevenbergen 19 April 1977.

63. On McKinsey's work for VNU, see Johannes and Cohen de Lara, Van Haarlem tot Manhattan, 80-85.

64. Wolters Kluwer archives, report by McKinsey, “Ontwikkelen toekomstige topstructuur", 10, 11, 15. 
board of directors and the supervisory board discussed McKinsey's report, they emphasized continuity. ${ }^{65}$

Kluwer's law group, having already established itself in Germany after the acquisition of Kommentator and Metzner, would now attempt to take over a larger German firm. It would then use the same pilot plant approach in France, but not in Belgium, where the market was considered to be too small, nor in Britain, where the legal system was too different from continental Europe. The science group would not take over foreign firms for the time being, but focus, instead, upon autonomous growth for which it saw ample opportunities. Its contribution to internationalization would continue to consist mainly in exports. Although generally opposed to joint ventures, Kluwer did establish one with Nijhoff's American distributor, in order to get to know the American market, as it had done with the pilot plants in Germany. ${ }^{66}$ The educational and general books groups would also continue autonomous growth, in spite of McKinsey's advice to start an aggressive acquisition campaign.

The profile the managing and supervising directors drew up for Klopper's successor in 1976 is a nice illustration of the type of manager Hofstede and Lawrence find typically Dutch. First of all, the new CEO should be a team worker, used to leading a decentralized firm; he should not be too autocratic and aggressive, but realize that there were several ways to obtain reasonable profits; he should have a genuine interest in the Works Council; and he should have experience in international expansion. ${ }^{67}$ On 1 January 1977, Bendert Zevenbergen, who had led the chemical firm Enka Glanzstoff in Wuppertal and had been deputy CEO at its holding company Akzo, took office. During the ten years in which he led Kluwer, the general management took a firmer lead in the firm, especially in matters of acquisition, at home and abroad. The supervisory board left important decisions more to the managers. ${ }^{68}$ Soon after taking office, Zevenbergen started a systematic survey of the possibilities of internationalization. The results of this survey, and the subsequent discussions, give a clear picture of basic approaches of international expansion within Kluwer. Let us take a closer look at them.

65. Wolters Kluwer Archives, Raad van Commissarissen, box 3.006, 11 November 75 .

66. Ibid.

67. Wolters Kluwer Archives, Raad van Commissarissen, box 3.006, 12 February 1976.

68. Wolters Kluwer Archives, Raad van Commissarissen, box 3.007, 31 August 77, 28 June 79. 
In February 1977, Zevenbergen sent the managers of the groups in the company (education, law, technical, scientific, and general) a notice setting out the main parameters of the problem, based on his previous experience at Akzo. ${ }^{69}$ He pointed out that expansion of the firm and the need to spread risks implied internationalization. This process, he said, had been too slow so far. The central management had left it mainly to the operating companies, which proceeded very differently. The decentralized approach also had the disadvantage that foreign firms operating on several markets would be insufficiently noticed by the specialized groups. ${ }^{70}$ A month later, Zevenbergen sent the managers a long list of questions, asking for a detailed assessment of the desirability and goals of internationalization, the countries where Kluwer had the best opportunities, the available manpower, possible strategies, and organizational implications. He also included a question about what the OLI-model calls "ownership advantages", or in his own words: "What 'contribution' (other than financial) could your group bring to an establishment abroad, in other words: what is your specific know-how? Do you believe that management and experts from the Netherlands should be sent abroad for a shorter or a longer period?" 71 Zevenbergen, therefore, saw ownership advantages, as we might expect, mainly in terms of knowledge and expertise.

The answers of the managers revealed great differences between the operating companies with respect to experience and confidence in internationalization, but all agreed it was necessary. The Educational Group, whose international activities focused upon technical textbooks, pointed to the need to cash in on expensive copyrights, especially on drawings, by using them for publications in different countries. A similar argument was put forward by the publishers of popular nonfiction, which also used a great deal of illustrations. The Law Group said that it had no option but to expand abroad, since Kluwer was already dominant in the Netherlands. The

69. The debate can be followed in detail in the Wolters Kluwer archives, collectie Zevenbergen, BZ 473, microfilm 6630-15, which contains reports and correspondence February-October 1977. Deliberations at ICU, or Wolters Samsom, were remarkably similar, partly because the firm was similar: Wolters was mainly an educational publisher, Samsom had grown large in government administration (forms, reference works on law, and so on). ICU seems to have been a bit more keen on the introduction of computer based systems than Kluwer at the time. See: Wolters Kluwer archives, archief Wolters Samsom, WSG 460 bijlage bij Raad van Commissarissen, 3 March 1976.

70. Wolters Kluwer archives, Zevenbergen collection, no date (c. April 1977).

71. Ibid, 1 March 1977. 
Scientific Group was treated separately, since its international activity consisted of export rather than running subsidiaries abroad.

As to the ownership advantages, the managers were consistent in their emphasis upon expertise, which they all formulated in terms of what the evolutionary theory calls "tacit knowledge", consisting of experience acquired over a long time and a certain style of management. The formulations were somewhat vague, but taken together they convey a sense of experience and confidence. "The most important know-how we may successfully apply internationally," wrote the Educational Group for example, "is not in patents, processes or products, but in the attitude of our people towards the market, which we cannot easily transfer to others. We therefore prefer to expand not too fast." And: "The organization of the group is not based upon explicit directives but upon a common way of thinking that has grown over the years, and by which decisions can easily be delegated. The manager of the group and his administrator 'supervise' this organization. Functionaries communicate directly across organizational boundaries." The Law Group wrote that Dutch managers would have to be sent abroad in order to transfer their knowhow. Local functionaries should work under Dutch managers. They mentioned loose-leaf and other, unspecified systems as a special advantage of Kluwer. ${ }^{72}$ A larger firm, wrote the Technical and Newspaper Group, should only be taken over if the local managers would accept "Kluwer people to supplement their know-how." This would be easier with smaller firms, several of which were available in Germany. ${ }^{73}$

The Kluwer board of directors concluded in April 1977 that expansion should take place by acquisition of firms abroad and at home, as well as by expansion of the already existing firms, rather than by starting wholly new establishments. All operating companies would work on this, while the general management would try to find a somewhat larger firm in Germany to take over. ${ }^{74}$

From August 1977 Zevenbergen and his staff undertook a systematic survey of German publishers that might be taken over-Germany being the country which all the managers Zevenbergen consulted

72. The unspecified systems were probably computer networks for jurisprudence, in which Kluwer claimed a pioneering role: Wolters Kluwer Archives, Raad van Commissarissen, box 3.007, 31 August 77

73. Wolters Kluwer archives, Zevenbergen collection, BZ 473, Reply by KDTU no date (Spring 77).

74. Wolters Kluwer archives, Zevenbergen collection, BZ 473, letter by B. Zevenbergen, 19 August 1977. 
had put on top of their list. Zevenbergen also used the services of the Industrie-Vermittlungsdienst (Industrial Agency) of the Deutsche Bank, which collected information about firms that might interest Kluwer and established the first contacts. ${ }^{75}$ Kluwer aimed at middlesized firms, that is, those having a turnover of between 25 and 50 million Deutsche Mark. ${ }^{76}$ In the annual reports, it spoke of a policy of "cautious expansion."77 But middle-sized firms turned out to be very expensive. This was also the case in the USA, where Kluwer tried to expand into some years later, because there were many rivals in takeover bids. Therefore, the going was slow. ${ }^{78}$ Nevertheless, small acquisitions in the fields of law, medicine, and education continued during the nineteen-seventies and eighties, at first mostly in Germany and Britain, during the 1980s also in France and the USA. ${ }^{79}$

On average, the activities abroad were more profitable than Kluwer's domestic activities. It was a major reason why the firm continued to grow in spite of domestic problems during the recession of the early 1980s. The second oil crisis led to a sharp downturn in the publishing business. The market for encyclopedias collapsed, general books declined, and so did advertisements, which supported its newspapers and magazines. The government cut back its budget for education. There was overcapacity in the printing business, while at the same time large investments were needed for new machinery. Publishing companies reacted by selling off or liquidating their printing firms and publishers of general magazines and books. Kluwer concentrated its efforts on the most profitable markets: science, professional and trade journals, and education (including courses and electronic media). It was part of a "retreat from conglomeracy" which was an international trend in business during the 1980s. ${ }^{80}$

In all, internationalization proceeded more slowly than Zevenbergen and his colleagues wished, but in 1986 foreign activities had increased significantly. Turnover abroad, for example, grew from

75. Wolters Kluwer archives, Zevenbergen collection, BZ 473, nrs. 28-99, exhange between Zevenbergen and representatives of the Deutsche Bank, August-October 1977.

76. Wolters Kluwer archives, collection Zevenbergen, BZ 473, reactions of the managers of the groups, March-April 1977; note by Resius, 25 July 1977; letter by Zevenbergen, 19 August 1977.

77. Kluwer, Annual report 1979, 9; Kluwer, Annual Report 1980, 9.

78. Wolters Kluwer Archives, Raad van Commissarissen, box 3.007, 15 February 1979.

79. Kluwer, Annual reports 1977-1990.

80. Jagersma, Multinationalisatie, 122; De Vries, Four windows, 142-43. Reed, e.g., sold its paper and paint plants, Thomson its oil, etc.: Graham, "Multinational publishing", 244. 
Table 3 Kluwer Turnover and Personnel, 1980-1986

\begin{tabular}{lcccc}
\hline & 1980 & 1982 & 1984 & 1986 \\
\hline Turnover in Netherlands (million guilders) & 676 & 785 & 892 & 966 \\
Index & 100 & 116 & 132 & 143 \\
Turnover abroad (in million guilders) & 134 & 171 & 236 & 269 \\
Index & 100 & 128 & 176 & 201 \\
Employees in the Netherlands & 4,102 & 4,117 & 4,082 & 4,034 \\
Index & 100 & 100.4 & 99.5 & 98.3 \\
Employees abroad & 392 & 498 & 581 & 787 \\
Index & 100 & 127 & 148 & 201 \\
\hline
\end{tabular}

Source: Kluwer, Annual reports, 1980-1986. ${ }^{a}$

a Turnover is here defined as "Omzet aan derden."

about 19 percent of total turnover in $1974^{81}$ to 28 percent in 1986 . The number of employees abroad continued to grow while their number in the Netherlands declined slightly (see table 3). One important boost to legal publishing consisted in the increasing number of laws and regulations of the European Union, which had to be translated into the languages of all the member states. ${ }^{82}$

In the summer of 1986, the Dutch publisher Elsevier, of which more below, proposed a merger with Kluwer. Elsevier was mainly active in scientific and legal publishing and its CEO, P. Vinken, saw the two firms as ideal partners. He also believed that as a result of increasing competition and the great merger movement only ten to twenty large international publishers would be left in the immediate future, and he wanted Elsevier to have a controlling position in one of them. The Kluwer managers, however, rejected the merger proposal because the organizational structure and corporate culture at Elsevier were too different. They also did not share Vinken's quasi-Darwinian “dinosaur theory” as it was sometimes called. ${ }^{83}$ Kluwer's CEO at the time, J. J. C. Alberdingk Tijm (who had succeeded Zevenbergen in 1987), believed that in the future, firms of different sizes would continue to prosper. ${ }^{84}$ One year later, Elsevier attempted a hostile takeover which failed, because a smaller Dutch firm, Wolters Samsom, succeeded in taking

81. Wolters Kluwer archives, archief Wolters Samsom, WSG 460, “Bijlage op internationalisatie Kluwer”' (1975), p. 2.

82. De Vries, Four windows, 217.

83. Vinken, in Elsevier's annual report for 1986, cited in De Vries, Four windows, 187. For the dinosaur theory, also embraced by Robert Maxwell, see Noble, "The media merger wave of the 1980s", 5 .

84. Quoted in De Vries, Four windows, 188. 
over Kluwer. After the merger, Wolters and Kluwer continued their internationalization together. ${ }^{85}$

Kluwer's internationalization strategy, therefore, consisted mainly in taking over small (family) firms abroad, as well as an occasional joint venture, by means of which knowledge of the foreign market was internalized. Expertise in international expansion was acquired by appointing a CEO with experience in this field, although Zevenbergen had been employed in an altogether different type of company. Another source of information was the German Vermittlungsdienst. German acquisitions served as a kind of test case or learning site. Although the central management took the lead in internationalization, Kluwer maintained its decentralized structure as the best means to use local knowledge and stimulate the entrepreneurial spirit in its managers.

\section{Elsevier: a Brief Comparison}

The basis for Elsevier's prominent international position as a scientific publisher was laid by J. P. Klautz, who after two years as secretary of the owner became managing director in 1929. He made the ailing business successful by publishing a new edition of a multivolume encyclopedia that had been one of Elsevier's first ventures, and attracting some novelists that became very popular. After the war, another edition of the encyclopedia, more popular novels, and Elsevier's Weekblad, an imitation of Time Magazine, were the bases for Elsevier's growth. Scientific publishing only became prominent after 1955, but the foundations of Elsevier's astonishing success in this field had been laid by Klautz during the decade before the war.

During the 1930s, Klautz started to publish works of German Jewish scientists who had run into trouble with the Nazi regime. In 1938, he published a very successful English edition of Paul Karrer's handbook of organic chemistry, and acquired English language rights for several other reference works by prominent German scientific publishers, such as Thieme and Springer. In 1945, Klautz created a special branch, Elsevier's Wetenschappelijke Uitgeverij (EWU) for these activities. The first scientific journal Elsevier published, Biochimica

85. De Vries, Four windows, 216. Whereas in 1987, 62 percent of sales were still in the Netherlands, six years later this figure had dropped to thirty seven. Sales in Europe accounted for 45 percent, 11 percent in the USA and 7 percent in other countries. 
et Biophysica Acta (started in 1947) also sprang from the work of a German scientist, Carl Oppenheimer, whose journal, Enzymologia, had been discontinued by the Nazis in 1941. Ironically, Klautz lost his position as managing director as a consequence of his most ambitious international venture: an attempt to conquer the American market for medical encyclopedias. A joint venture with a small university press in Houston turned out to be a costly failure. When Klautz finally left Elsevier in 1953, EWU worked for a small international market and profitability was low. Like Kluwer and other Dutch publishers, Elsevier had a sales office in Belgium, and its encyclopedia sold well in the Belgian market.

Klautz's successor, the economist Dolf van den Brink, aimed at a steady profitability of the firm by means of a countercyclical policy. He argued that multivolume encyclopedias, appearing in the course of several years and paid for in advance by customers, attenuated the influence economic downturns such as during the Korea crisis in 1950 and the short recession in 1957. So did scientific books and journals, especially the latter, because they were sold by subscription. Scientific works were, according to Van den Brink, less vulnerable to competition from television than general fiction and magazines. Consequently Elsevier started to publish a whole range of encyclopedias in Dutch (for ladies, agriculture, technology, and so on) as well as scientific works in English for the international market. The scientific market grew spectacularly during the Cold War years, when all western countries invested huge sums in scientific research and higher education. ${ }^{86}$

From 1955, EWU started to grow quickly and already in 1961 Publishers weekly called Elsevier "one of the world's leading publishers of scientific books."87 Elsevier's successes have been attributed to the fact that it produced a new type of scholarly journal. In most countries, including the US, science publishing was in the hands of either scholarly societies or university presses. Their journals covered broad areas of learning, such as physics or chemistry. Elsevier's new journals, in contrast, were either more specialized (for example, nuclear physics) or they covered an interdisciplinary field (like biochemistry). This, together with a highly selective editorial

86. CBS (Dutch Statistics), Tachtig jaren statistiek in tijdreeksen (Den Haag, 1979), 48.

87. Publisher's weekly 16 April 1962, reprinted in Elsevier's Annual report 1961, 28. 
policy, quickly earned Elsevier great prestige in the international scientific community. ${ }^{88}$

In 1969 and 1971, Elsevier acquired two Dutch scientific publishers, the Noord-Hollandsche Uitgevers Maatschappij and Excerpta Medica, which proved to be very important for Elsevier's subsequent development. Both had German roots. M. D. Frank, who led the Noord-Hollandsche Uitgevers Maatschappij, had worked as a trainee at the Akademische Verlagsanstalt in Leipzig in 1934, and Excerpta Medica was started as a limited liability company in 1947 by German immigrants and Dutch physicians, publishers, and bankers. ${ }^{89}$ In 1969 , the Noord-Hollandsche Uitgevers Maatschappij published thirty scientific journals in English. Most of the copies were sold abroad. ${ }^{90}$ Excerpta Medica published excerpts from medical journals, which helped doctors keep abreast of the rapidly growing international literature. During the sixties, it employed some 100 Dutch and some 4,000 foreign doctors, who processed about 250,000 medical publications a year. ${ }^{91}$ Excerpta Medica was important to Elsevier because of its pioneering electronic databases, providing Elsevier with a headstart in this new field. The neurosurgeon, Pierre Vinken, who had led Excepta Medica from 1963, became the Managing Director of Associated Science Publishers, which in 1969, succeeded EWU as Elsevier's scientific division. Internationalization continued apace, with acquisitions and establishments, during the nineteen-seventies, in Mexico, Spain, Brazil, Ireland, Great Britain, and the USA. In 1975 scientific publications already accounted for 27 percent of Elsevier's turnover. ${ }^{92}$

Like other large publishers, Elsevier diversified during the nineteensixties. For example, in 1968, Elsevier took over the Dutch firm, Misset, a publisher of professional and trade journals, in a joint venture with the British IPC Business Press. As at Kluwer, book shops and printing firms were acquired. Some foreign firms were bought, among others, Phaidon (art books), in London in 1974, and the New York firm Dutton, a publisher of general books and children's books in $1975 .{ }^{93}$ Van

88. Meadows, "European science publishing and the United States", 241, $244-45$.

89. Van Leeuwen, "The decisive years for international science publishing in the Netherlands", 256, 262-63.

90. Van Leeuwen, “The decisive years"; Frank, "Internationaal uitgeven”, $74-84$.

91. Vermeulen and De Wit, Onder uitgevers, 22; Elsevier, Annual reports 1970 and 1971.

92. Wolters Kluwer archives Wolters Samsom, map WSG 460, 'Bijlage op internationalisatie Elsevier', (1975) 9.

93. Ibidem, 8. 
den Brink believed in a differentiated, decentralized firm. "As a consequence of language, local peculiarities, motivation and patterns of distribution, publishing differs very much per country. It is therefore an activity that has to be carried out in a decentralized way.",94

When Van den Brink retired and Vinken took over in 1979, acquisitions were at first continued (e.g., Congressional Information Service Inc. in Washington, the publisher of the American Congress). But from 1980, the international recession started to hit Elsevier in about the same way as it affected Kluwer: encyclopedias, general books, and printing were now losing money; revenue from advertisements went down, while international scientific publishing remained very profitable. Elsevier's reaction was similar to Kluwer's: firms publishing general books, newspapers, and magazines were sold, and so were bookshops and printing firms. Acquisitions abroad were temporarily halted. (see table 4)

There were also differences between Elsevier and Kluwer, however. First, Vinken acted quicker and in a harsher way. In 1984, he announced that firms that did not make a 20 percent profit would be sold. ${ }^{95}$ Secondly, unlike Kluwer, he abandoned the idea of a decentralized company. He argued that this had made sense during the period of expansion and diversification, but that in adverse times power should be centralized. The division structure was abolished. Each part of the firm now reported directly to the Executive Board, each member of which took responsibility for one of the main areas of Elsevier's activities. ${ }^{96}$ And third, the company was geared increasingly towards the English language market. Elsevier wanted to invest especially in the USA, because it considered the European market too fragmented. ${ }^{97}$ Vinken was a man of strong opinions, who liked to express his preference for an Anglo-Saxon style of management, geared toward quick and high profits for the investors, and opposed to the soft, "Christian" style he believed to be prevalent in the Netherlands. "Enterprise is war", he declared in an interview. He regarded the Dutch language as a dialect doomed to disappear. In the near future, publishing would largely be in English and would be concentrated in ten to twenty large companies. He attributed his failed attempts to integrate the large Dutch publishing firms to differences

94. Elsevier, Annual Report 1976, 8.

95. Elsevier, Annual Report 1984, 9.

96. Elsevier, Annual Report 1981, 9, 11.

97. Elsevier, Annual Report 1984, 9. 
Table 4 Elsevier Turnover and Personnel, 1979-1986

\begin{tabular}{lcccc}
\hline & 1980 & 1982 & 1984 & 1986 \\
\hline $\begin{array}{l}\text { Turnover in the Netherlands } \\
\quad \text { (million guilders) }\end{array}$ & 1,315 & 1,292 & 1,429 & 1,562 \\
Index & 100 & 99 & 108 & 119 \\
$\quad \begin{array}{l}\text { Turnover in American subsidiaries } \\
\quad \text { (million guilders) }\end{array}$ & 74 & 113 & 172 & 299 \\
Index & 100 & 153 & 232 & 404 \\
Employees in the Netherlands & 8,085 & 7,206 & 6,840 & 6,460 \\
Index & 100 & 89 & 85 & 80 \\
Employees abroad & 1,431 & 1,169 & 1,097 & 1,397 \\
Index & 100 & 82 & 77 & 98 \\
\hline
\end{tabular}

Source: Elsevier annual reports 1979-1986 ${ }^{a}$

a The annual reports do not allow to use exactly the same categories as with Kluwer, in table 3: instead of presenting the turnover in all countries outside the Netherlands, as compared to total turnover, we can only show turnover of the American division, which represents only part of the sales in the USA. Again, "turnover" is "omzet aan derden".

between his hard-boiled style and the softer Dutch style prevailing in the other companies. ${ }^{98}$

In the short run and in financial terms, the new strategy was very successful. Already in 1984, profits had increased by 40 percent and Elsevier took the offensive again. During the next few years, several US firms were taken over, as well as some British ones. Most of these takeovers were small firms (like Damar and Gordon, and the journals Laser and optronics and Fiberoptics News), but some were very large, like the American Springhouse Corporation, for which Elsevier paid a hundred million dollars. ${ }^{99}$ Vinken said in 1988, that two-thirds of Elsevier's profits were made abroad, and half of that in the USA. ${ }^{100}$ The next tables (table 5) show that Elsevier succeeded completely in becoming one of the great scientific publishers in the world.

\section{Conclusions: Patterns of Internationalization}

The Kluwer and Elsevier cases confirm several aspects of the evolutionary theory on the internationalization of business. They

98. For Vinkens views, see two interviews: Van Wermeskerken, De jaren 90, 227-54; Van Amerongen, PJV. For a refutation of the "dinosaur theory", see Noble, "Mergers and acquisitions of professional and scholarly publishers" and Wössner, "European media markets in the 1990s".

99. Greco, “Mergers and acquisitions in publishing, 1984-1988”, 33.

100. Wermeskerken, De jaren 90, 230. 
Table 5 The Largest Scientific Publishers in the World, 1985

\begin{tabular}{lcc}
\hline \multicolumn{1}{c}{ Publisher } & Books & \\
\hline Wiley & Country & $\begin{array}{c}\text { Number of titles } \\
\text { (rounded numbers) }\end{array}$ \\
Academic Press & USA & 10,000 \\
Elsevier Science Publishers & USA & 8,000 \\
Plenum & NL & 4,000 \\
Pergamon & USA & 4,000 \\
McGraw-Hill & UK & 3,500 \\
Springer Verlag & USA & 3,000 \\
Blackwell Scientific & Germ & 2,500 \\
\hline & UK & 1,650 \\
\hline \multicolumn{1}{c}{ Publisher } & Journals & \\
Elsevier Science Publishers & Country & (rounded numbers) \\
Pergamon & NL & 610 \\
Springer Verlag & UK & 367 \\
Academic Press & Germ & 257 \\
Plenum & USA & 189 \\
Wiley & USA & 159 \\
Blackwell Scientific & USA & 133 \\
Karger & UK & 102 \\
\hline
\end{tabular}

Source: P.K. Jagersma, Multinationalisatie van Nederlandse dienstenondernemingen (Tilburg, 1994) 76.

also suggest some qualifications and refinements, which may be tested in further studies. The cases clearly corroborate the paramount importance of knowledge and learning in the publishing field, as well as the importance of the economic and cultural history of the countries in which publishers build up their savoir faire. As to the types of knowledge involved and the way these are acquired, we believe our case studies may add some insights.

There were two basic types of international expansion in the publishing industry. Scientific publishing was mainly an export business, which operated upon the world-wide English language market. The beginning of international scientific publishing in the Netherlands owed much to German know-how and Hitler's expulsion of Germany's greatest scientific talents. Thus the contingencies of geography created the first opportunities. The postwar expansion was part of the rapid growth and internationalization in science, and the use of the English language after the Second World War. Much growth could be generated by firms based in the Netherlands, because the knowledge needed for this type of publishing was least bound to national cultures. When acquisitions took place, the firms most 
sought after were in Great Britain and the USA, which controlled specific international market niches.

The second type of expansion was in professional and educational publishing, which followed a different and more complicated logic. Fiscal and legal publishing differed fundamentally from scientific publishing in that the USA and Great Britain, with their very different legal systems (and the USA with its fifty states with their own constitutions), were difficult markets from the Dutch point of view. These branches of publishing, therefore, were more continental-European, and the publications tended to appear in different languages, because the information they contained was more bound to national cultures and laws. This also held for other professional publications, although to different extents. Technical works, for example, were often in English. Educational publications, on the other hand, had to fit into national curricula and were usually published in different national languages.

In other words, while scientific publishing required a detailed knowledge of international developments in the sciences, which could be based in one center in any country, professional and educational publishing required much more knowledge of local institutions, laws, and habits. Greenfield investments would, therefore, be extremely risky. The most effective way to internalize knowledge of foreign markets was by taking over firms in other countries. But learning had to proceed in small steps. Taking over a large firm with a large market share was not only expensive, it would also create difficulties in integrating the new firm and applying homegrown management capabilities to the newly acquired activities. These capabilities constituted another form of knowledge that was considered crucial in international expansion, besides knowledge of foreign markets. It was much more implicit, defined in terms of experience accumulated over a long period of time, a way of doing things that was critical to Kluwer's success both at home and abroad. This ruled out joint ventures in principle, although this form of cooperation might be used incidentally as well.

But where did the management capabilities come from that gave Kluwer and Elsevier managers such confidence in going abroad? Generally speaking, this kind of knowledge was broadly available in the Netherlands as a consequence of its unusually diversified and internationally oriented economy. These characteristics go back to the seventeenth century, but most relevant for our study is the geographical position of the Netherlands as a nodal point between the two industrial superpowers of the late nineteenth century, Germany and Britain, as well its extremely rich colony in the Far East. 
From the nineteen-fifties, when many publishing houses made the transition from family business to managerial firm, managers who had started their careers in internationally oriented firms entered the publishing business. At Kluwer, for example, Gorter could build on his experience in the East Indies and the textile trade, and Zevenbergen applied an approach to internationalization he had learned at ENKA Glanzstoff in Germany. ${ }^{101}$ The sequence is very clear in the case of Kluwer. Sanders, Gorter, and Klopper, aided by experts of the $\mathrm{ABN}$, transformed the family firm into a diversified, and eventually, an international company. Then Zevenbergen speeded up internationalization, explicitly applying chemical industry methods to the publishing business.

The Kluwer case also appears to confirm the existence of a national management style, which manifested itself in the process of internationalization as well. The profile drawn up for Kluwer's new CEO in 1976 emphasized the need for a cooperative style and a long-term view, not solely geared to shareholder value. Elsevier's Van den Brink, although he seems to have been more autocratic than the Kluwer managers, confirmed the reasonableness of this method of management for the publishing business, as we saw. His successor Vinken however adopted a very different manner. It is easy to explain this from Vinken's personality, which made him embrace an Anglo-Saxon style and reject the "Dutch Christian style" which he despised. But another explanation seems to be just as important. Scientific publishing encouraged centralization, while professional and especially educational publishing required decentralization. Thus, although national experiences do contribute to the development of certain styles of management, these styles have as much to do with the specific characteristics of the publishing business and of the different kinds of markets publishers work for.

Types of knowledge required for internationalization depended on markets targeted-more universal in the case of science, more nationally specific in the case of professional and educational publishing. More fundamental than these forms of explicit knowledge were managerial skills and capabilities developed during the domestic expansion of the firms. The publishing houses discussed in this article imported much of this implicit knowledge from other Dutch firms which had more international experience.

101. See Willison, "Massmediatisation”, 581. For a similar development at VNU see Johannes and Cohen de Lara, Van Haarlem naar Manhattan, 85. 
Bibliography of Works Cited

Books

Altbach, P. G., and E. S. Hoshino, eds. International Book Publishing: An Encyclopedia. London, 1995.

Amatori, Franco, and Geoffrey Jones, eds. Business History Around the World. Cambridge, 2003.

Beusekamp, W., and J. Schoonbrood. De overval van Elsevier op Kluwer. Amsterdam, 1987.

Bloom, Helen, Roland Calori, and Philippe de Woot. Euro Management: A New Style for the Global Market. London, 1994.

Bonin, Hubert. Transnational Companies (19th-20th Centuries). Paris, 2001.

Buckley, Peter J., and Pervez N. Ghauri, eds. The Internationalization of the Firm. London, 1999.

CBS. Tachtig jaren statistiek in tijdreeksen. Den Haag, 1979.

Chandler, Alfred D., Jr., Franco Amatori, and Takashi Hikino, eds. Big Business and the Wealth of Nations. Cambridge, Mass., 1997.

Coser, Lewis A. Books. The Culture and Commerce of Publishing. New York, 1982.

De Jong, H. W. Fusies en overnames: Het concentratieproces in de Westerse markteconomie van de twintigste eeuw. Den Haag, 1988.

De Vries, Joh. Four Windows of Opportunity: A Study in Publishing. Amsterdam, 1995.

Dunning, John. The Globalization of Business. London, 1993.

Hagedoorn, J. and R. Narula. Evolutionary Understanding of Corporate Foreign Investment Behaviour: US Foreign Direct Investment in Europe. Maastricht, 1995.

Hofstede, Geert. Culture's Consequences: International Differences in Work-Related Values. Beverly Hills, 1984.

. Cultures and Organizations: Intercultural Cooperation and its Importance for Survival. London, 1991.

Jagersma, P. K. Multinationalisatie van Nederlandse dienstenondernemingen. Tilburg, 1994.

Johannes, G. J. and M. Cohen de Lara. Van Haarlem tot Manhattan: Veertig jaar VNU 1965-2005. Een uitgeverij in de lage landen wordt international informatie- en mediaconcern. Amsterdam, 2005.

Jones, Geoffrey. Multinationals and Global Capitalism from the Nineteenth to the Twenty-First Century. Oxford, 2005.

The Evolution of International Business: An Introduction. London, 1996.

Merchants to Multinationals: British Trading Companies in the Nineteenth and Twentieth Centuries. Oxford, 2000.

Jones, Geoffrey, ed. Transnational Corporations: A Historical Perspective. London, 1993.

, and Schroter, Harm, eds. The Rise of Multinationals in Continental Europe. Aldershot, 1993. 
Klautz, J. P. In de ban van mijn schaduw. Huizen, 1987.

Lawrence, Peter. Management in the Netherlands. Oxford, 1991.

N. V. Uitgevers-Maatschappij Æ. E. Kluwer. Gedenkboek uitgegeven ter gelegenheid van het vijftigjarig bestaan N.V. Uitgevers-Maatschappij E.E. Kluwer, 1889-1939. Deventer, 1939, (note to production; author here is the company, not a person).

Roberts, Joanne. Multinational Business Service Firm: The Development of Multinational Organisational Structures in the UK Business Services Sector. Aldershot, 1998.

Schiffrin, A. The Business of Books: How International Conglomerates Took Over Publishing and Changed the Way We Read. London and New York, 2000.

Schröter, H. G. Aufstieg der kleinen: Multinationale Unternehmen aus fünf kleinen Staaten vor 1914. Berlin, 1993.

Sluyterman, Keetie E. Kerende kansen: Het Nederlandse bedrijfsleven in de twintigste eeuw. Amsterdam, 2003. (Translated as Sluyterman, Keetie E. Dutch Enterprise in the Twentieth Century: Business Strategies in a Small Open Economy. London, 2005).

Van Amerongen, Martin. PJV. Amsterdam, 1995.

Van den Brink, R. E. M. De uitgever heeft vele gezichten. Amsterdam, 1979.

Economische structuur en ontwikkeling van de informatiemedia in Nederland 1938-1985, in het bijzonder die met betrekking tot de uitgeverij. Leiden, 1987.

Van Krevelen, L. De Stijl van de uitgever. Amsterdam, 2002.

Van Wermeskerken, P. C. De jaren 90: Visie van Nederlandse topondernemers. Weert, 1988.

Van Zanden, J. L. Een klein land in de twintigste eeuw: economische geschiedenis van Nederland 1914-1995. Utrecht, 1997. (Translated as van Zanden, J. L. The Economic History of the Netherlands 1914-1995. London, 1998).

Vermeulen, R. and Ph de Wit. Onder uitgevers. Nijmegen, 2000.

Articles and Essays

Buckley, Peter J., C. L. Pass, and Kate Prescott. “The Internationalization of Service Firms: A Comparison with the Manufacturing Sector." In The Internationalization of the Firm, eds. Peter J. Buckley and Pervez N. Ghauri. London, 1999, pp. 149-65.

Byrnes, Robert F. "The French Publishing Industry and Its Crisis in the 1890's." In The Journal of Modern History 23 (September 1951): 232-42.

Coster, W. "Denker tussen vraag en aanbod. Aebele Everts Kluwer: 1861-1933." Deventer Jaarboek (Deventer, 1989): 6-49.

Daalder, H. "The Sudden Revolution and the Sluggish Aftermath: A Retrospect Since 1968." In Universities, Politicians and Bureaucrats, eds. H. Daalder and E. Shils. Cambridge, Mass., 1982, pp. 489-510. 
De Goey, F. "Dutch Overseas Investments in the Very Long Run (c. 1600-1900)." In Multinational Enterprises from the Netherlands, eds. R. van Hoesel and R. Narula. London, 1999, pp. 32-60.

De Nederlandse Bank. "Monetair Financiële Statistieken 1982-2002." Statistisch Bulletin, 58 (October 2003): 230-1.

Dongelmans, B. P. M. “Foreign Trade." In Bibliopolis: History of the Printed Book in the Netherlands. Zwolle, 2003, 195.

Dunning, J. "Multinational Enterprises and the Growth of Services: Some Conceptual and Theoretical Issues." The Service Industries Journal 9 (January 1989): 5-40.

Frank, M. D. "Internationaal Uitgeven." In Het geheim van de uitgever, ed. A. Nuis. Amsterdam, 1978, pp. 74-84.

Gales, B. P. A., and K. E. Sluyterman. "Outward Bound. The Rise of Dutch Multinationals." In The Rise of Multinationals in Continental Europe, eds. G. Jones and H. G. Schröter. Aldershot, 1993, pp. 65-98.

Graham, G. "Multinational Publishing.” In International Book Publishing: An Encyclopedia, eds. P. G. Altbach and E. S. Hoshino. London, 1995, pp. 242-9.

Greco, A. N. "Mergers and Acquisitions in Publishing, 1984-1988: Some Public Policy Issues.” Book Research Quarterly 5, no. 3 (1989): 25-44.

Johanson, J., and J.-E. Vahlne. "The Internationalization Process of the Firm-A Model of Knowledge Development and Increasing Foreign Market Commitments." Journal of International Business Studies 8 (1977): 23-32.

Jones, Geoffrey. "Business Enterprise and Global Worlds." Enterprise and Society 3 (December 2002): 581-605.

and Mary B. Rose. "Family Capitalism." Business History 35 (Fall 1993): 1-16.

Kendrick Noble, J. "Mergers and Acquisitions of Professional and Scholarly Publishers: A Contrarian View." Book Research Quarterly 5, no. 3 (1989): 45-50.

Klein, Maury. "Coming Full Circle: The Study of Big Business Since 1950." Enterprise and Society 2 (September 2001): 425-60.

Kogut, B. "The Evolutionary Theory of the Multinational Corporation: Within- and Across-Country Options." In International Business. An Emerging Vision, eds. B. Toyne and D. Nigh. Columbia, 1997, pp. 470-88.

"Country Capabilities and the Permeability of Borders." Strategic Management Journal 12 (1991): 33-47. and H. Singh. "The Effect of National Culture on the Choice of Entry Mode." Journal of International Business Studies 19, no. 3 (1988): 411-32.

, and U. Zander. "Knowledge of the Firm and the Evolutionary Theory of the Multinational Corporation." Journal of International Business Studies 24 (1993): 625-45.

, and U. Zander. "Knowledge, Market Failure and the Multinational Enterprise: A Reply." Journal of International Business Studies 26, no. 2 (1995): 417-26. 
MacIver Neiva, Elizabeth. "Chain Building: The consolidation of the American Newspaper Industry, 1953-1980.” Business History Review 70 (Spring 1996): 1-42.

Meadows, A. J. "European Science Publishing and the United States." In Development of Science Publishing in Europe, ed. A. J. Meadows. Amsterdam, 1980, pp. 237-50.

Narula, R., and Roger van Hoesel. "Outward Investment from the Netherlands: Introduction and Overview.” In Multinational Enterprise from the Netherlands, eds. Roger van Hoesel and Rajneesh Narula. London, 1999, pp. 1-31.

Shelley Rubin, Joan. "Self, Culture, and Self-Culture in Modern America: The Early History of the Book-of-the-Month Club." The Journal of American History 71 (March 1985): 782-806.

Sluyterman, Keetie E. "Internationalisation of Dutch Accounting Firms." Business History 40 (Spring 1998): 1-21.

"De drukkerij-uitgeverij Misset en de opkomst van vakbladen, 1900-1940." Jaarboek voor de Geschiedenis van Bedrijf en Techniek 3 (1986): 205-29.

Sparling, Robert R. “Het Externe Vermogen van Nederland.” In Statitisch Bulletin, 57 (February 2002): pp. 10-2.

Springhall, John. 'Disseminating Impure Literature. The 'Penny Dreadful' Publishing Business Since 1860." The Economic History Review New Series 47 (August 1994): 567-84.

Teulings, C. H. I. E. M. “Concernvorming in de uitgeverij.” In Het geheim van de uitgever, ed. A. Nuis. Amsterdam, 1978, pp. 92-101.

Van Iterson, A., and R. Olie. "European Business Systems: the Dutch Case." In European Business Systems: Firms and Markets in their National Contexts, ed. R. Whitley. London, 1992, pp. 98-116.

Van Lente, Dick. "Copy, Composition, Printing (Printing Presses, Printing ink) and Correction" [1910-Present]." In Bibliopolis. History of the Printed book in the Netherlands, eds. M. Van Delft en and C. De Wolf. Zwolle, 2003, pp. 224-8.

"Ingenieurs en de vormgeving van de Nederlandse samenleving.'" In Techniek in Nederland in de twintigste eeuw, vol. VII: "Techniek en modernisering. Balans van de twintigste eeuw," ed. J. W. Schot. Zutphen, 2003, pp. 197-231.

Van Kranenburg, H., M. Cloodt, and J. Hagedoorn. “An Exploratory Study of Recent Trends in the Diversification of Dutch Publishing Companies in the Multimedia and Information Industries." International Studies in Management and Organization 31/1 (Spring 2003): 64-86.

Van Krevelen, L. "Van liefhebberij tot cultureeel ondernemerschap. Over de ontwikkeling van de literaire uitgeverij in Nederland." Jaarboek voor Nederlandse boekgeschiedenis 10 (2003): 13-50.

Van Leeuwen, J. K. W. "The Decisive years for International Science Publishing in the Netherlands after the Second World War." In Development of Science Publishing in Europe, ed. A. J. Meadows. Amsterdam, 1980, pp. 251-68. 
Van der Weel, A. H. "Foreign Trade." In Bibliopolis: History of the Printed Book in the Netherlands. Zwolle, 2003, pp. 242-3.

Verbeke, A. "The evolutionary view of the MNE and the future of internalization theory." Journal of International Business Studies 34:6 (2003): 498-504.

Wilkins, Mira. "Dutch Multinational Enterprise in the United States: A Historical Summary." Business History Review 79 (Summer 2005): $193-275$.

Willison, I. "Massmediatisation: Export of the American Model?" In Les mutations du livre et de l'édition dans le monde du XVIIIe siècle á l'an 2000, eds. J. Michon and J. Y. Mollier. Quebec, 2001, pp. 574-89.

Wössner, M. "European Media Markets in the 1990s." Book Research Quarterly 6:3 (1990): 37-43.

Würzner, M. H. "De Duitse emigrantenliteratuur in Nederland, 1933-1940.”' In Berlijn-Amsterdam 1920-1940: Wisselwerkingen, ed. K. Dittrich. Amsterdam, 1982, pp. 114-5.

Magazines and Newspapers

“Today's best book profits are in professional publishing." Publishers Weekly, 21 Mar. 1977

Unpublished Sources

Van Lente, D., “Kluwer, family, experts and managers: 1920-1960”, Conference paper, Stockholm, September 2004, available at http://hdl.handle.net/1765/6880.

Wolters Kluwer Archives, at the company's main office, Appollolaan 153, Amsterdam, the Netherlands. 